\title{
The Politics of Access to Expensive Drugs: INESSS and the Innovative Pharmaceutical Industry
}

\section{La politique de l'accès aux médicaments coûteux : l'INESSS et l'industrie pharmaceutique novatrice}

\author{
ज्ञ \\ DAVID HUGHES, MA \\ Sciences Humaines Appliquées; Bioéthique \\ Université de Montréal \\ Montréal, QC
}

\begin{abstract}
The innovative pharmaceutical industry employs thousands of people in Quebec and so has the ability to exert strong political pressure; the public statements of Sanofi-Aventis concerning the provincial reimbursement of certain expensive drugs are an example. "Maintaining a dynamic biopharmaceutical industry" is one of four main axes of the drug policy of Quebec's ministry of health. However, this role of government should not take precedence over the efficient and equitable management of health resources. We defend the legitimate and responsible choice of the Institut national d'excellence en santé et en services sociaux du Québec (INESSS) to require an acceptable cost-effectiveness ratio from expensive new drugs.
\end{abstract}

\section{Résumé}

L'industrie pharmaceutique novatrice emploie des milliers de personnes au Québec et est donc en mesure d'exercer une forte pression politique; les déclarations publiques de SanofiAventis au sujet du remboursement provincial pour certains médicaments coûteux en sont un exemple. «Le maintien d'une industrie biopharmaceutique dynamique » est un des quatre 
axes de la politique du médicament du ministère de la Santé du Québec. Toutefois, ce rôle du gouvernement ne devrait pas prévaloir au détriment d'une gestion efficace et équitable des ressources de la santé. Nous défendons le choix légitime et responsable de l'Institut national d'excellence en santé et en services sociaux du Québec (INESSS) qui consiste à exiger un ratio coût-efficacité acceptable pour les nouveaux médicaments coûteux.

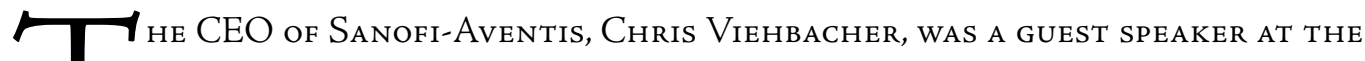 17th International Economic Forum of the Americas, held in Montreal in June 2011. \\ L Mr. Viehbacher told La Presse affaires that he deplored the fact that some drugs are} not covered by Quebec's Public Prescription Drug Insurance Plan:"I think the patients are in trouble because the experts may say that a drug is important in a province ... but in Quebec it is not available." In addition, he said this affects the innovative ${ }^{1}$ pharmaceutical industry: "We face both the threat of reduced reimbursement of drug costs and at the same time, we are obliged to invest more and to run greater risk for research and development" (Croteau 2011).

Although he did not emphasize the link, Mr. Viehbacher's comment came a week after the decision of the Institut national d'excellence en santé et en services sociaux du Québec (INESSS) not to include - for reasons of cost-effectiveness - Sanofi's Multaq (dronedarone) to the list of reimbursed drugs. The INESSS evaluation found that the drug would lead to an additional $\$ 100,000$ in healthcare costs per life-year gained (even more if one considers quality of life) (INESSS 2011). This cost-effectiveness ratio shows a low level of efficiency. In addition, the drug would provide little or no advantage compared to the cheaper alternatives that are already reimbursed (Le Heuzey et al. 2010; Freemantle et al. 2011). The Canadian Expert Drug Advisory Committee of the Common Drug Review has also recommended that Multaq not be listed (Canadian Agency for Drugs and Technologies in Health 2010). However, British Columbia has decided to reimburse the drug through the $\mathrm{BC}$ Pharmacare program (BC Ministry of Health).

In April 2011, the head of the Canadian branch of Sanofi-Aventis, Hugh O'Neill, had also raised the issue of public reimbursement of drugs in front of businessmen of the Canadian Club of Montreal (Mercure 2011a). Sanofi-Aventis employs approximately 600 people in Quebec. In 2010, it dismissed 150 employees across the country citing, among other reasons, the reluctance of some provinces to reimburse several new drugs (Larocque 2010). In addition, Pfizer Canada CEO Paul Lévesque referred to insufficient public reimbursement in order to justify industry non-compliance with its commitment to invest $10 \%$ of its revenues in R\&D in Canada (Mercure 2010).

These comments are not unlike those of the Quebec Cancer Advocacy Coalition. The coalition, comprising patients and oncologists in partnership with drug manufacturers, has made numerous public appearances to denounce the fact that some expensive cancer drugs are not reimbursed in Quebec for reasons of cost-effectiveness but are available in Ontario and 
British Columbia (Soucy 2010). One example is Erbitux (for colorectal cancer), which provides generally less than two months of additional survival and costs about $\$ 7,000$ per month of treatment (around \$180,000 per quality-adjusted life-year) (Conseil du médicament 2010; CED 2011). Nevertheless, Erbitux is reimbursed in Ontario through the Exceptional Access Program and in British Columbia through the Compassionate Access Program.

Studies have shown that there are significant variations among provinces regarding the scope of drugs covered by public insurance plans (Grégoire et al. 2001; Macdonald and Potvin 2004; Menon et al. 2005; Khoo et al. 2007; Hughes 2012). These studies have shown that drug coverage in Quebec is among the most extensive in Canada. In 2001, Grégoire and colleagues (2001) even advanced the hypothesis that this predisposition of Quebec to welcome the claims of the manufacturers could be linked to an economic development policy: "The high proportion of new drugs reimbursed in Quebec may reflect an industrial policy to encourage innovation through support of the local research-based pharmaceutical industry" (2001: 311; see also Griller and Denis 2008). But with the arrival of new drugs that are very expensive and that provide little benefit, INESSS made the legitimate decision to require a reasonable cost-effectiveness ratio. ${ }^{2}$

It is not clear whether reimbursing additional drugs leads to more local investment and innovation. Some economists believe that the subsequent innovation and economic spin-offs that are expected to be driven by the inclusion of a new drug should be included in costbenefit calculations and reimbursement decisions. Doing so would give an incentive for local investment and innovation (Goldman et al. 2010). In contrast, other health economists argue convincingly that it is the role of the private sector to anticipate and invest in future benefits. Moreover, asking insurers to pay an innovation premium would amount to "pay[ing] twice for the same benefits, i.e., payment for current and future value now and then payment again for the same value if and when it is realised" (Claxton et al. 2011: 16). Finally, there is no guarantee that the investment encouraged by such innovation premiums will be made in the province or country where the premium was granted. Investment will be made in whatever jurisdiction offers the best R\&D environment (Claxton et al. 2011).

Two other elements of the Quebec policy designed to attract and retain investment are taxation measures and the "15 years rule" (Griller and Denis 2008). In Canada, Quebec's corporate tax rate is slightly lower than the average (for large corporations in 2007). In addition, Quebec has the most generous tax credit rate for R\&D in Canada. The " 15 years rule" provides protection for intellectual property rights for patented drugs for 15 years from their introduction into the Quebec market. Hence, the Quebec public plan has an obligation to pay for the brand-name product for about five years longer than in the rest of Canada even if a less expensive generic is available. ${ }^{3}$ This approach results in a significant increase in profits for the industry and costs to insurers. In exchange, the industry has pledged to sell its drug at the best available price in Canada (BAP rule). ${ }^{4}$

Despite those measures, hundreds of jobs have been eliminated in Quebec in recent years. ${ }^{5}$ In October 2010, Merck closed its Kirkland laboratory, resulting in the loss of 180 
jobs; and in January 2012, Sanofi announced lay-offs of around 100 people in Canada, mostly in Quebec. In February, AstraZeneca announced the shutdown of its Montreal research centre, which employs about 135 people. Roche's recent decision to create 200 jobs in Ontario is interpreted by some observers as a sign of weakness in Quebec's approach and the result of confidential agreements between Ontario and the industry (Mercure 2011b).

Faced with the astronomical prices of many new drugs, some provinces - including Ontario and British Columbia - now have recourse to confidential agreements with manufacturers (Gagnon 2011; Bourassa Forcier 2010). They agree to reimburse expensive, low-efficiency drugs in exchange for discounts and possibly local investment. The secret discounts that Ontario and British Columbia are receiving might be one reason why these provinces have agreed to list drugs that Quebec has rejected. For example, the Ontario evaluation report for Erbitux shows that the Committee to Evaluate Drugs (CED) recommended the drug not be funded, but the executive officer decided to fund Erbitux following a cost agreement with the manufacturer. ${ }^{6}$ However, because the prices are kept secret, this practice contravenes an agreement between industry and Quebec according to which it would pay the lowest price in Canada.

The Quebec government has a mandate to promote the development of the pharmaceutical industry, which occupies an important place in the Quebec economy. "Maintaining a dynamic biopharmaceutical industry" is even one of the four main axes of the Ministere de la santé et des services sociaux's drug policy (Gouvernement du Québec 2007). Registration of a product on the list of publicly funded drugs (and, indirectly, that of private insurers) has a direct impact on market access and the income of drug manufacturers. But should the economic health of this industry influence decisions about drug coverage? Must the consequences of such decisions on this industry be a criterion for evaluating whether or not to list a drug?

The government also has, above all, the mandate to manage health resources responsibly and efficiently. Some new drugs are extremely expensive and provide few benefits compared to alternatives that are already reimbursed. Is the inclusion of these new drugs an ethically responsible and equitable use of scarce resources when health needs are many and affect different groups of patients? "How much resources is it reasonable to spend on a particular health problem considering all the health needs of the population?" (Conseil du médicament 2007: 6). Is it not also necessary to control the rapid increase in drug spending in order to preserve the continuity of drug supplies and to ensure that future generations also have access to essential medicines (Daniels 2006)?

The evaluation of health technologies is a highly social and political process - and a site of power struggles (Lehoux and Blume 2000); the INESSS is not immune to this reality (Doucet 2006). The innovative pharmaceutical industry employs around 8,000 people in Quebec and has the ability to exert significant political pressure. However, decisions about the public reimbursement of drugs should not aim to increase profits for the industry, but instead, should foster fair and efficient use of taxpayer money in order to have the greatest positive impact on population health. 


\section{ACKNOWLEDGEMENTS}

This work was financially supported by Fonds québécois de recherche sur la société et la culture (FQRSC), Groupe de recherche interuniversitaire et interdisciplinaire MéOS (www.meos.qc.ca) and Programme de doctorat en sciences humaines appliquées de l'Université de Montréal.

The author, who accepts full responsibility for the content of this paper, would like to thank anonymous reviewers and Bryn Williams-Jones for their comments and suggestions.

Correspondence may be directed to: David Hughes, Faculté de pharmacie, Université de Montréal, Case postale 6128, succ.Centre-ville, Montréal, QC, H3C 3J7; e-mail: david.bughes@umontreal.ca.

\section{NOTES}

${ }^{1}$ As opposed to generic drug companies, innovative companies manufacture brand-name drugs protected by patents. These drugs are the product of expensive research and development.

2 INESSS has no explicit cost-effectiveness threshold. For British agency NICE, a QALY's value is $£ 20,000$ $£ 30,000$ (around CAD\$50,000). Interventions with a cost above this threshold are less likely to be recommended for reimbursement by the NHS.

${ }^{3}$ The Canadian protection of intellectual property rights for drug manufacturers is 20 years from the date of patent application. Half of this period is necessary to conduct the clinical trials and obtain regulatory approval. The manufacturers have the other half of the 20-year period to recover R\&D costs and make a profit before generic drugs are allowed to enter the market.

${ }^{4}$ See: Regulation Respecting the Conditions Governing the Accreditation of Manufacturers and Wholesalers of Medications, schedule 1, 1(4).

${ }^{5}$ In addition, since 2000, manufacturers have not fulfilled their 1987 commitment to invest $10 \%$ of their revenues in $\mathrm{R} \& \mathrm{D}$ in Canada.

${ }^{6}$ Because British Columbia evaluation reports are not made public, it is difficult to know whether there has been such an agreement. The CED Ontario report for Multaq is not available.

\section{REFERENCES}

Bourassa Forcier, M. 2010 (December 17). "Médicaments: de nouveaux produits en échange d'investissment." La Presse.

British Columbia Ministry of Health. 2011. BC Pharmacare Formulary. Retrieved February 28, 2012. <http:// www.health.gov.bc.ca/pharmacare/benefitslookup/faces/Search.jsp $>$.

Canadian Agency for Drugs and Technologies in Health. 2010 (May 27). "CEDAC Final Recommendation: Dronedarone Hydrochloride." Ottawa: Author.

Claxton, K., M. Sculpher and S. Carroll. 2011 (February)."Value-Based Pricing for Pharmaceuticals: Its Role, Specification and Prospects in a Newly Devolved NHS." York: Centre for Health Economics, University of York. Retrieved February 28, 2012. <http://www.york.ac.uk/media/che/documents/papers/researchpapers/ CHERP60_value_based_pricing_for_pharmaceuticals.pdf $>$.

Committee to Evaluate Drugs (CED). 2011. “Cetuximab for Metastatic Colorectal Cancer.” Toronto: Ministry of Health and Long-Term Care.

Conseil du médicament. 2007."Le Choix des médicaments assurés au Québec: une démarche responsable et transparente." Quebec: Author.

Conseil du médicament. 2010."Erbitux - Avis de refus." Quebec: Author.

Croteau, M. 2011 (June 10). "Québec doit réviser ses critères de remboursement des médicaments." La Presse.

Daniels, N. 2006. "Equity and Population Health: Toward a Broader Bioethics Agenda." Hastings Center Report 36(4): $22-35$. 
Doucet, H. 2006. “Politiques publiques et critères d'inscription des médicaments dans le régime public québécois d'assurance médicaments." Éthique publique 8(2): 113-27.

Freemantle, N., C. Lafuente-Lafuente, S. Mitchell, L. Eckert and M. Reynolds. 2011. “Mixed Treatment Comparison of Dronedarone, Amiodarone, Sotalol, Flecainide, and Propafenone for the Management of Atrial Fibrillation." Europace 13(3): 329-45.

Gagnon, M.-A. 2011 (July).“Des ententes secrètes nuisibles.” Protégez-vous. Retrieved February 28, 2012. <http:// www.protegez-vous.ca/sante-et-alimentation/ententes-secretes-nuisibles.html>.

Goldman, D., D. Lakdawalla, T.J. Philipson and W. Yin. 2010. “Valuing Health Technology at NICE:

Recommendations for Improved Incorporation of Treatment Value in HTA." Health Economics 19(10): 1109-16.

Gouvernement du Québec. 2007.“La Politique du médicament.” Québec: Ministère de la santé et des services sociaux.

Grégoire, J.-P., P. Macneil, K. Skilton, J. Moisan, D. Menon, P. Jacobs et al. 2001.“Inter-provincial Variation in Goverment Drug Formularies." Canadian Journal of Public Health 92(4): 307-12.

Griller, D. and D. Denis. 2008. How to Build a Pharmaceutical Industry: Québec's Story. Montreal: SECOR

Consulting. Retrieved February 28, 2012. <http://www.secorgroup.com/files/pdf/books/how_to_build_a_pharmaceutical_industry.pdf $>$.

Hughes, D. 2012 (in press). “L'Accès aux anticancéreux au Canada: comparaison entre le Québec, l'Ontario et la Colombie-Britannique." Pratique et organisation des soins 43(1): 9-18.

Institut national d'excellence en santé et en services sociaux (INESS). 2011. "Avis au ministre sur Multaq." Quebec: Author.

Khoo, K., R. Colucci, W. Hryniuk, J. Ragaz, S. Sehdev and C. Savage. 2007.“The New Wave of Cancer Drugs.” In Cancer Advocacy Coalition of Canada, Report Card on Cancer in Canada 2007. Toronto: Cancer Advocacy Coalition of Canada.

Larocque, S. 2010 (May 5). “Sanofi-Aventis supprime 70 postes dont 30 au Québec." La Presse.

Le Heuzey, J.-Y., G.M. De Ferrari, D. Radzik, M. Santini, J. Zhu and J.-M. Davy. 2010. “A Short-Term, Randomized, Double-Blind, Parallel-Group Study to Evaluate the Efficacy and Safety of Dronedarone versus Amiodarone in Patients with Persistent Atrial Fibrillation: The DIONYSOS Study." Journal of Cardiovascular Electrophysiology 21(6): 606-07.

Lehoux, P. and S. Blume. 2000. “Technology Assessment and the Sociopolitics of Health Technologies.” Journal of Health Politics, Policy and Law 25(6): 1083-120.

Macdonald, K. and K. Potvin. 2004. "Interprovincial Variation in Access to Publicly Funded Pharmaceuticals." Canadian Pharmaceutical Journal 137(7): 29-34.

Menon, D., T. Stafinski and G. Stuart. 2005. “Access to Drugs for Cancer: Does Where You Live Matter?" Canadian Journal of Public Health 96(6): 454-58.

Mercure, P. 2010 (December 8). “Investissements en recherche: Pfizer remet en question son engagement." La Presse.

Mercure, P. 2011a (April 12). “Vers de plus petits centres de recherche." La Presse.

Mercure, P. 2011b (August 22). “Roche investit en Ontario: un signal d'alarme pour le Quebec." La Presse.

Soucy, L.-M. 2010 (April 23).“Des failles importantes en cancérologie.” Le Devoir. 